\title{
Exile and Homeland Trauma: Constructing Memories in Rithy Panh's The Missing Picture
}

\author{
Guglielmo Scafirimuto \\ Université Paris III
}

\begin{abstract}
:
This article focuses on the question of an exiled artist's representation of traumatic and missing memories. Through an analysis of Rithy Panh's documentary The Missing Picture (2013), the paper discusses the relationship between memory and imagination, the risk of forgetting and the attempt to create a new picture of a repressed past.
\end{abstract}

Keywords: Cambodia, genocide, trauma, re-enactment, documentary

\section{Introduction}

In which way can the process of constructing memories of a traumatic past be an act of survival and regeneration for an exiled artist? Migrant identity is a transnational and multilayered process, a constantly (re)negotiated work of memory and narration. Especially in the post-traumatic condition of exile, individual identity needs to construct meaning in a larger framework of belonging and narrative. Many exiled artists retrospectively look at homeland memories and images to represent the fragments of their personal histories inscribed in the official History of the nation. But what happens when there is no image of these homeland memories and no connection between personal history and official History?

My contribution will focus on the question of representing traumatic and missing memories for an exiled artist in autobiographic film. Through an analysis of Rithy Panh's documentary The Missing Picture (2013), I will discuss the relationship between memory and imagination, the risk of forgetting and the attempt to create a new picture of a repressed past. The traumatic context will be that of the 1975 Khmer Rouge genocide in Cambodia, where Rithy Panh, barely a teenager at the time, lost his parents and part of his family. Leaving the country, after a brief period in a refugee camp in Thailand, Panh went to Paris, France, where he started a career as a film director, always directing his attention to the post-Khmer Rouge situation in his homeland. 


\section{The archive and the quest for the image}

The Cambodian Communist Party, named Khmer Rouge, supported by North Vietnam and other international forces like China and the Soviet Union, after the victory in the Cambodian Civil War against the Khmer Republic, entered the capital Phnom Penh in April 1975 and changed the name of the country to Democratic Kampuchea. The Revolution, headed by the Khmer Rouge leader Pol Pot, forced the Cambodians for four years into forced labour camps in the countryside and caused the death of approximately two million people (25\% of the country's population), provoked by mass executions or by starvation and disease. The genocide and the Khmer Rouge regime ended only in 1979 when the Socialist Republic of Vietnam defeated Democratic Kampuchea. One of the consequences of this period was of course a massive exile of Cambodian people, many of whom, like Rithy Panh, flew to France (Cambodia was part of French Indochina until 1953). The genocide was systematically denied until recent times, and it was only in 2014 that two Khmer Rouge leaders were condemned with the imputation of crimes against humanity.

The Missing Picture is born of a lack of representation: Panh realizes that there are no archival images of the lives of the Cambodian people in the labour camps during the period of the Democratic Kampuchea. He decides to fabricate some new images himself - using clay figurines - for a re-enactment of this traumatic and missing past, starting from his personal memories. These images, constituting an alternative, subjective and creative process of representation, claim for the re-appropriation of History for the survivors. The film medium can facilitate the reactivation and transmission of individual and collective memories of a past that has been disowned due to the absence of justice and recognition. The Missing Picture won several prizes around the world, including the top prize in the section Un Certain Regard at the 2013 Cannes Film Festival, and it is one of Panh's several films based, as we will see, on the concept of the duty of memory.

The insistence on the historical personal quest is clear from the first sequence of the film: a bunch of rolls of old films occupies the entire archival room and the eye of the director is checking all the photograms. This gesture of verification introduces us to the common genesis of a documentary project in which the director takes on the role of the historian, with his emphasis on uncovering the archaeological layers of the past. The archive is a metonymy of the official History, but if it is normally included to reinforce the rhetoric strategies of a documentary discourse telling the 'truth', in this film it constitutes a space of fiction full of self-proclaimed and partial signs of a nation controlled by a totalitarian regime. The photograms disclose the traditional dance of a woman in slow motion, a classical picture that refers to a certain stereotypical visual repertoire of Cambodia and to the inability of the archive to accurately represent the real past of the country.

Masking the real means repression and that is represented by the following shot: the violence of the sea waves pouring directly over the camera opens the question of erasing, covering, and taking away, a metaphor of the power of the dictatorship. However, the disappearance prepares the ground for the return, recollection and the need to restart from a tabula rasa. Rithy Panh begins his preliminary exposition in a slow and solemn voice-over that accompanies the dramatic tone of the narrative all along the film. Plantinga's term of "projected world" (Plantinga 86) - the representational 
space where the author can formulate his point of view and make his arguments seems appropriate for the diegetic universe of this film, based primarily on projection (of memories, of culpability, of other movies). The voice-over starts: "In the middle of life, childhood comes back. It is a bittersweet water. I look for my childhood. Like a missing picture. Or rather it is my childhood that calls to me". The return to childhood at a mature age is a common topic of autobiographical narrative, but it is particularly violent when referring to a brutal genocide trauma for an individual living in exile.

\section{Trauma and re-enactment}

The film then reveals its dispositif showing a close-up of a hand sculpting a little clay figurine: in the absence of authentic pictures of the historical period of the genocide, the director tries to re-enact some of his past memories, that coincide with this collective lack of representation. Rithy Pan requested the help of many artisans to make it possible: we witness the important process of breathing new life into his family members, his native village, and some scenes of his life and of Cambodian people in general. The painted little figurines, accurately disposed in a number of tableaux vivants recreating many different locations and scenarios, crowd this sort of memory theatre in which alternative histories demand their place. An internal montage is already present because of the precise disposition of the figurines, but other techniques like zooming in and out, as well as panoramic and traveling shots in the tiny space of the scenography contribute to the narrative mise en scène and to the montage of the events. All the costumes, the gestures, the objects and the houses are very well reconstructed through the figurines, and the Cambodian music of the 1970s take us back to that period. This mimesis is nuanced by the feeling of entering the naïve world of a child carefully playing with his toys. Nevertheless, the autobiographical elements, evoking family moments, passages of his life, sensorial details like sounds, smells and colours, become fundamental parts of the larger frame of the history of the genocide. The re-enactment sequences allow us to combine individual and collective histories. The coloured images of the figurines are alternated with the black and white images of the archival footage (propaganda material), mixing in that way personal and subjective memories of his childhood with the official History of the nation, in a chronological narrative of the events.

In The Missing Picture Panh stresses the brutality of the communist militarization of the country and the dehumanization of the deportation to the camps. The "new revolution" carried out by the Khmer Rouge obliged people to abandon their names, their families, their villages and their memories. This trauma is linked by the re-enactment to the question of the possibility of representation of collective tragic events, like genocide. The archival footage he found is only a series of propaganda images showing the celebration of the revolution, the happy crowd, the army, and the parades. Any trace of what this revolution signified for most of the Cambodian population (deportation, exploitation, execution) is not visible in the archive, which also ends up being a reminder of absence and oblivion. Michael Chanan affirms as well this dimension of loss in the archive: "The archival images are more than historical records, but the markers of loss and trauma both national and individual" (Chanan 240). The 
reconstruction of the details of these traumatic memories is a way for the artist to create a possible representation after all these years, to give a concrete shape to these phantoms, but also to try to get rid of them. Or probably, to just render the obsession less frightening, in a sort of cathartic effect produced by the achievement of the documentary 'mission'. If Esther Mujawayo writes that "on the inside, there is no end to a genocide" (quoted by Rosoux 78), the artist's function is in fact to intervene as a spokesman of the victims to demonstrate the distinction between "living memory" the memories shared by the individuals - and "official memory" - the public and in stitutional construction of History (Rosoux 57). Ricœur's concept of "manipulated memory" (Ricœur 97) as an ideological manipulation of power regarding national history can be applied to the "obliteration of the past" (Rosoux 73) in the context of Cambodia.

\section{Exile and duty of memory}

In this way we can remark that Rithy Panh, in The Missing Picture, faces not only an intimate work of mourning as a person but also a "duty of memory" as an artist. Ricœur defines the "duty of memory" in relation to the sentiment of justice towards others, the community who shares the experience of loss, transforming the memory to commemoration: "Duty of memory is the duty of doing justice, through memory, to someone else" (Ricœur 108). Processes of historicization of a collective past often arise from the original trauma of an individual that triggers self-exploration and a potentially subversive use of autobiography - like mimicry or repetition of the wound in the re-enactment sequences of the film - in order to overcome the trauma (Burgelin 100). The tabula rasa, the emptiness, like the distance of the exile, can then become a point of fracture from which to exercise a new creativity. Panh calls for the need of the "reconstruction of the Self", the resistance against the repression: "they can steal an image, not a thought". The right of self-representation through the re-appropriation of the history, catalysed by an act of creativity and imagination, is the possibility of the rehumanization of the Cambodian people.

In opposition to the effort of the totalitarian communist regime to turn the population into an anonymous mass of laborers, Panh affirms in the film the unique individuality of Cambodian people living before and during the revolution. He talks about his brother, who used to play rock and roll guitar, and disappeared in 1975 right after the arrival of the Khmers. He recalls the memory of his dad and his mom, who dreamed about a free country and who died in the genocide. He describes himself as a child discovering the world of cinema, the colours, the dances, the dreams and the evasion of going to the movie theatre. There are many moments in the film where the two kinds of images - archival footage and figurine re-enactment - find a dialogue, a mutual overlap, when, for example, an old movie is projected on the façade of a clay house. Imagination, memories and history cohabitate in the same "projected world". The director's clay alter ego, staring at the military planes in the sky, expresses (by the voice over) the frustration of not having a photo camera to record that reality: "Let people know... the missing picture is us". Panh reminds us of the wishful thinking of all those who were repeating the slogans of the revolution all over the world without knowing the reality of the repression in his homeland, without seeing the images. 
The director compares the lies of the ideological system of the revolution with the illusion of truth of the cinematic apparatus. "There is no such thing as the truth. There is only cinema. Revolution is cinema". This is how the subjective discourse about the missing pictures meets the political denunciation of the communist regime in Cambodia. The Khmer Rouge - and we can see it in their propaganda movies - built a world of fiction, an image of change, which has only degenerated into false promises, misery, violence and destruction. Can we understand this regime by looking at the pictures shot by Khmer Rouge camera operators? What do these images tell us? What is missing? The film proves that archival images as documents are not enough. Panh feels a "duty of memory", a responsibility toward whoever is missed and invisible in this story, the poor, forgotten dead people, and of course his family. He wants to complete the archive, to fill the hole, to repair the "obliteration".

This brings us to the main reason for the project, very common among exiled artists: the sense of guilt. His distance, his first attempt to remove the homeland memories, his trajectory of an intellectual man (he imagines in the film that his village can see all his interviews on a big screen and judge him) serve only to make him desire to be useful for his original country and community. We can think about the "double absence" of the exile as Sayad called the in-between condition of the emigrant subject of not truly being in the hosted nation while no longer being in the homeland either. The necessary continuity between these two places is represented by the figure of himself as a child. This child is following him - he always talks about the return of childhood, and "the childhood as a question" - as a trace of his ongoing interrogations about the past. Bearing witness becomes his way of finalizing his mourning, of giving a name to this emptiness and of finally being able to bury his family. The high-angle shot of his buried family is yet another impossible image, like the genocide, pushing the limits of the representation of death through the help of animation, an act of no return. The Missing Picture, then, is a gesture of survival and regeneration.

\section{Conclusion}

Panh is deeply concerned with the relationship between memory and imagination in collective and individual constructions of identity. If the re-enactment part could be moved by Sartre's definition of imagination as a "magical act" (Ricœur 65) as the apparition of the absent in the present (similar to the Platonian eikon), the film project overall is probably more nourished by the Aristotelian anamnesis, as a process of active recuperation, repetition and representation of the past as a struggle against oblivion (Ricœur 18). Exile, even in a context of a profoundly traumatic retrospective look at the homeland, can be a creative position for the artist who wants to transmit his "projected world" to others through a self-reflexive mode. Because, as Marie-Noëlle Schurmans claims, transmission is always also a transformation (Schurmans 167-169), and the film can constitute another historical document, maybe another (incomplete) archival source, but above all a symbolic reparation for the condition of exile. Panh clotures The Missing Picture by reminding us of the political responsibility of the legacy of his action: "Of course I have not found the missing pictures. I looked for them in vain. A political film has to discover what it has invented. So I fabricate this picture, I look 
at it, I cherish it, I keep it in my hand like a beloved face. I now give you this missing picture in order to prevent it from stopping to look for us".

\section{References}

Burgelin, Claude. "Ecriture de soi, écriture de l'Histoire : esquisses autour d'un conflit". Ecriture de soi, écriture de l'histoire. Ed. Jean-François Chiantaretto. Paris: In Press Editions, 1997. 97-108.

Chanan, Michael. The Politics of Documentary. London: British Film Institute, 2007.

Panh, Rithy. The Missing Picture. Cambodia/France. Catherine Dussart Productions and Bophana Production. 2013. Film.

Plantinga, Carl R. Rhetoric and Representation in Nonfiction Film. Cambridge: Cambridge University Press, 1997.

Ricœur, Paul. La mémoire, l'histoire, l'oubli. Paris: Editions du Seuil, 2000.

Rosoux, Valérie. "Mémoire et résolution des conflits. Quelle transmission au lendemain d'une guerre?". Transmission, mémoire et reconnaissance. Ed. Nathalie Burnay. Fribourg: Academic Press Fribourg, 2011. 57- 80.

Sayad, Abdelmalek. La double absence. Des illusions de l'émigré aux souffrances de l'immigré. Paris: Editions du Seuil, 1999.

Schurmans, Marie-Noëlle. "Transmission et transformation". Transmission, mémoire et reconnaissance, Ed. Nathalie Burnay. Fribourg: Academic Press Fribourg, 2011. 167178. 